\title{
Between Empire and Anti-Empire: African Mission in the $21^{\text {st }}$ Century
}

\section{Stuart C Bate OMI}

\section{Summary}

There is always empire and anti-empire in societies. An analytical lens needs to see both together to provide a better understanding of human society. This is particularly important when it comes to issues of religion which resides in some form in both empire and anti-empire. This presentation will unpack five points. Firstly it will present a brief historiography of the existence of empire and anti-empire mainly but not exclusively as it relates to Christianity. Secondly it will provide the main parameters of a social analysis of the nature of empire and anti-empire. Thirdly it will articulate the specific role of religion (again mainly Christianity) in the societies of empire and anti-empire. Fourthly it will apply these findings to the specific context of Africa (mainly South Africa) indicating two signs of empire and anti-empire in our past and present context. Finally it will provide some goals for Mission in 21st century Africa which go beyond the empire/anti-empire paradigm. These are based on a vision of transformational authority centred in the paschal mystery.

Keywords and Phrases African Christian Mission; Globalisation; Religion and Society; Theology of Empire; Theology of Antiempire; Theology of Authority; Development; Spirituality; Conversion.

\section{Author}

Stuart C. Bate is an Oblate of Mary Immaculate Priest. Currently he is responsible for Research and Development at St Joseph's Theological Institute, Cedara, KwaZulu-Natal. He is also honorary senior lecturer in the School of Religion, Philosophy and Classics at the University of KwaZulu-Natal. Email: scbate@omi.org.za.

\section{Introduction: Empire, Anti-Empire and Religion: Articulating Analytical Lens of Faith}

There has been a considerable amount of recent literature on the relationship between empire and religion based on the premises that empires use religion to achieve their goal of domination and growth and religions use empire to perpetuate their own growth and hegemony (Carey, H. 2008; Rieger 2007; Horsley 2003). Conversely there is a body of recent literature particularly in Biblical studies which focuses on the anti-imperial nature of the scriptures (Cf. Friesen 2001; Horsley 2008; Yamakazi-Ransome 2006). In addition there has been a strong body of theological literature particularly in the last half century promoting the premise that theology promotes liberation from oppressive regimes (Cf. Gutiérrez 1973; Boff \& Boff,. 1984; Nolan, \& Broderick 1987; Boesak 2009). 
I suggest that there is always some aspect of empire and anti-empire in societies. An analytical lens needs to see both together to provide a better understanding of social dynamics. This is particularly important when it comes to issues of religion which resides in some form in both empire and anti-empire. However, I want to propose that the empire/anti-empire paradigm needs to be overcome to create a Missiology for $21^{\text {st }}$ century Africa.

\section{A brief histography of empire, anti-empire and Christianity Christianity Empire and Anti-empire in the Scriptures and the Early Church}

Several empires provide the background context to the Old and New Testaments. ${ }^{1}$ Empires are criticised in the Old Testament because they are destructive of God's people by placing them in captivity or because they rule unjustly. Nevertheless, some Old Testament texts are more supportive of political governance. They usually relate to the establishment of the Jewish Kingdom or its restoration. The notion of the messiah is linked to these texts (Carey H. 2008:181). In the New Testament, a number of texts, such as Mark 12 and Romans 13, take the position that God is supportive of human political institutions (Carey H. 2008 181). Other texts such as some of those relating to the Kingdom of God and to the establishment of the Church seem to justify empires. ${ }^{2}$

However, many of the New Testament narratives are critical of empire. These include the narrative of Jesus' birth, those parts of his preaching which point to anti-empire values in God's kingdom, Jesus before Pilate and the narrative of the passion and crucifixion. This has prompted the suggestion that "Jesus' mission was primarily in opposition to Roman imperial rule [which] poses a challenge to the standard, older construction of Jesus as opposed to 'Judaism"' (Horsley 2008:95). Opposition to empire is probably most clearly seen in the book of revelation which "provides a devastating attack on imperial rule which is radical and uncompromising" (Carey H. 2008: 181). These examples have prompted the comment that the New Testament "was written about and by politically powerless people" (Cobb 2003 §V).

\section{Christianity and Empire from the Edict of Milan to the Reformation: Christendom}

In $313 \mathrm{AD}$, the situation in the Roman Empire changed radically as Constantine gave state recognition to Christianity. Then, in 380, Theodosius I established the State Church of the Roman Empire. ${ }^{3}$ From this period,

Egypt, Assyria, Babylon and Rome are the principal ones

2 The term "The Church" capitalised in this way refers to the one Church specified in the creeds. All Christian churches accept this teaching of one church but differ in their interpretation of how it manifests in the different churches. 
Christianity began a massive growth leading to the gradual emergence of what has been called Christendom. ${ }^{4}$

As the Church and its leaders increasingly acquired rights and responsibilities within the empire, patristic theologies played an important role in clarifying the disputes between Christians. This provided a solid base for the Church to grow within different cultures and contexts. ${ }^{5}$

Paradoxically, the "barbarian" invasions and occupations empowered the growth of Christendom as the leaders of these tribes often converted to the Christianity they found whilst destroying the old empire and its power. Emerging from this was a serious of powerful church and political leaders who sowed the seeds for political and social theologies which captured the minds and hearts of the people of the time. By the eight century, Charlemagne's armies established political unity in the West and the Byzantine Empire held sway in the East so that until the eleventh century there was a clear planting of Christendom in the political reality of what is today called Europe.

Gradually, throughout the middle ages, the power of the Church and in particular the papacy rose so that by the twelfth century "the exercise of papal jurisdiction became habitual" as both temporal matters and spiritual ones were referred to it. Consequently, "the papacy had become de facto the centre of a vast Christian nation" (Urquhart 1908). This was a situation that would last until the reformation.

\section{Christianity and Anti-Empire from the Edict of Milan to the Reformation: Christendom}

As Christendom extended its influence, groups of Christians appeared manifesting signs of anti-empire. These signs included theological differences with the established church as well as local socio-cultural concerns driving the anti-empire resistance.

3 The Edict of Milan in 313 allowed Christians to practice their religion and build churches. It also restored confiscated properties to them. In 380 Theodosius I issued De Fide Catolica formalising Catholicism as the State Church of the Roman Empire (Halsall 1997); cf. McGrath 2006: 414.

4 'The term 'Christendom' is recorded in late ninth century Anglo-Saxon England and has no exact parallel in the Latin or Greek words used previously to designate Christian adherence ,Christianitas or oikumene" (Herrin 1987: 8). It refers to the society emerging after the breakdown of the Roman Empire, in which Christian faith rather than imperial rule becomes the defining feature of society.

5 These clarified important matters such as the Canon of scripture, the theological nature of Christ, and the relationship between Christianity and cultures of the empire. (see: McGrath 1998: 17-93). 
The Bogomils emerged in the tenth century during the first Bulgarian empire and they spread to the north under the influence of the first and second Bulgarian empires. Socio-cultural factors encouraging their growth included reaction to the Greek language and culture of the Byzantine church and to the introduction of the feudal system which robbed people of the control over their land. ${ }^{6}$ Other groups included the Bosnians and the Cathars. ${ }^{7}$ Many of these groups shared some gnostic and dualist beliefs and the term Albigenses was applied to them by the Catholic Church which condemned them as heretical. ${ }^{8}$ Consequently they suffered political persecution and often destruction. ${ }^{9}$

One important cause of the growth of so many new forms of Christianity was the change in social context. In the twelfth and thirteenth centuries "a new order began to appear. Towns and cities grew in wealth and size. An urban population composed chiefly of merchants and artisans gained in prominence. Feudalism showed signs of decay" (Latourette 1938:431). The new movements were often present in these newly urbanized areas where they reflected the needs of people in this new social context. Another factor was the growing dissatisfaction with the reality of corruption and power play within the Church. This included disaffection with some of the self-serving motivations of Christendom and abuses attributed to the clergy.

These examples of the medieval conflict between empire and anti-empire were about to discharge into the biggest of all: the reformation in the 16th century. On the level of linguistic analysis, prescinding from the ecclesial issue, one should note that anti-empire is quintessentially exemplified in the term "protestant". ${ }^{10}$

6 "Bogomilism was clearly in part a nationalistic Bulgarian reaction against Byzantine imperialism, culture and faith. It was also in part a protest against the morals of the Orthodox clergy" (Latourette 1938: 442).

7 "The Cathars claimed that there existed within humankind a spark of divine light. This light, or spirit, had fallen into captivity within a realm of corruption-identified with the physical body and world. This was a distinct feature of classical Gnosticism, of Manichaeism and of the theology of the Bogomils" (Cathari" New World Encyclopaedia).

8 "The name Albigenses, given them by the Council of Tours (1163) and was for a long time applied to all the heretics of the south of France. They were also called Catharists (katharos, pure), though in reality they were only a branch of the Catharistic movement" (Weber 1907).

9 This strategy was performed by the emperor in calling councils to decide issues in regard to the earlier heresies and the Pope calling councils in the later. The result in both cases was always a political persecution of the heretical group a clear manifestation of a theological judgement motivating political acts.

10 Probably the most famous protest in this regard are Martin Luther's 95 theses against indulgences, which was clearly an act of protest. It should be noted that Luther probably did not use the term Protestant himself. It appears in 1529 at the "protestation" at the 


\section{The nature of Empire and Anti-Empire}

\section{The Characteristics of Empire}

An empire is traditionally defined as "supreme and extensive (political) domination" (Oxford Concise Dictionary). It usually refers to the situation where one nation or tribe extends its power over many others through a process of military, economic and cultural force. Empire is most fully present when control is established over all the means of production within its domain. ${ }^{11}$

Power in empires is usually crystallised in terms of a central figure, the emperor, often symbolised in superhuman, mythical and even supernatural forms. This leads to the establishment of cults within the empire. The values which inform laws and define correct behaviour within the domain are also usually attached to the symbol of the emperor figure who may in some cases be a historical figure whose symbolic emperor persona continues: passed down to subsequent leaders.

Power is administered in empires through elites who control the movement of resources of the domain by means of political, socio-economic, and cultural forces. They have access to the means of production and administration of the legal system. The rewards of empire are focussed on the elites and laws within the empire will generally work in their favour.

Empires are comprehensive in their control of power which they seek on the levels of transcendence, of culture, of social structure, and of daily human behaviour. On the transcendent level power is exercised through foundational myths, and the persona of the Emperor expressed in supernatural and superhuman language. Power on the level of culture is exercised through inculcated values and ethics and their manifestation in law. Empires impose structural control through political systems, socio-cultural structures end economic systems. Finally on the level of behaviour in daily human life, control is coercive through the army, the police and other security agencies.

Empires that are successful normally ensure that the quality of life for the majority of the people is improved. This is done through structures which ensure public order and stability and the use of economies of scale to ensure greater access to resources. In addition they create time for cultural pursuits and for this reason, knowledge, education and the arts thrive within empires. It is for this reason that the value of empires within human society should not easily be discounted. When they fail to achieve these goals they create opposition from within and structures of resistance begin to emerge. It is these structures of resistance that are the manifestation of anti-empire.

Diet of Speyer.

11 "Empire is commonly used with reference to a dominant nation or regime's control of the territory, people or resources of another country" (Horsley 2003: 6). 


\section{The Characteristics of Anti-empire}

Anti-empire is a resistance to empire. It occurs when the power of empire is experienced by people as oppressive or corrupt or destructive of their life. Anti-empire may manifest itself in any or all of the levels of power. Resistance on the level of transcendence happens by establishing new transcendent systems usually through religion. On the level of culture, values, ethics and law, resistance takes the form of new beliefs, values and laws proposed and adopted within the places they have hegemony. Resistance on the structural level occurs by advocating for, adopting and establishing new political systems, social structures and economic systems in the domains they control. Resistance on the level of behaviour in daily human life usually happens first within small groups who propose and adopt new lifestyles.

If anti-empire grows and captures public commitment on the same four levels it has the possibility to become empire itself. Christianity was anti-empire and became the Holy Roman Empire. America was anti-British empire and became empire itself in the 20th century. The Central African Empire of Bokassa is a surreal example of how the anti-empire of the struggle against colonialism became "empire" in a bizarre mirroring of Napoleon I after the French revolution.

Today, a new globalised networked world is emerging. It is becoming extremely powerful and often overwhelming. In this way it is manifesting some of the characteristics of empire as indicated in 2.1 above but not those of human identity around a clearly defined human elite or an emperor figure. Indeed it is digital in nature. The interconnected reality has its own goals, strategies, and systems but people have to participate in the network because of the demands of their lives at work, in the economy and in State bureaucracy. ${ }^{12}$ One result is that there do not appear to be social institutions powerful enough to transform its unacceptable face. The network treats connected people not as human beings but as digital entities. ${ }^{13}$

12 The network controls the economy, issues of national identity, licences, passports and other national bureaucratic issues and people increasingly interface with it at the work place. Consequently the main characteristic of this new social structure is a "bipolar opposition between the Net and the self' (Castells 2000:3).

13 These new humans have aspects of the cybernetic about them and so the notion of what it means to be human is challenged. And indeed digital philosophies of the human person are emerging, for example, interpreting humanity in terms of genes and memes. Digital humanity is articulated physically in terms of genes and the culturally in terms of memes. Such an understanding has profound questions for the nature of human life which impact upon ethical systems based on human dignity. If humans are basically genes and memes all with their own propensity and desire to reproduce then the nature of what we call the human person is contingent not upon a creator or indeed a non spiritual evolution but rather upon the genes and memes themselves which become the real actors. For an insight on human culture understood from the perspective of memes see Balkin 1998. 
Consequently, it is threatening because it cannot be humanised. This leads to concerns about the nature of human identity in such a globalised networked world. ${ }^{14}$ People respond by attempting to create local centres of human identity. But these only comprise aspects of defence, refuge and resistance because of the perception of the network's power. ${ }^{15}$ Thus they exhibit some characteristics of anti-empire constructions. Castells (2000: 12) identifies four principal ways in which such identity reconstruction is currently going on. These are religious fundamentalism, nationalism, ethnic identity and territorial identity. Resistance responses to globalisation contain a component of rejection together with a grudging use of the system when it can further local goals. Examples of this kind of response include the rise of religious fundamentalism, the worldwide growth of cults and the growth of ideologically based movements employing military violence to achieve their goals. ${ }^{16}$

\section{Religion and Empire}

Religion has played a role in almost every empire. The relationship between religion and empire is a complex dialectic of power and control. There are three possibilities. In the first case empire has clear hegemony and controls religion. In the second case religion has clear hegemony and controls the nature of empire. In addition there is a third case where one finds a more equal power relationship and control within the empire is partially from the empire and partially from religion.

\section{When Empire Dominates Religion}

In this case religion works in support of empire. Examples include the Roman Empire from Caesar to Theodosius and the period of European colonialism by Holland, France and Britain in the nineteenth century. In this paradigm: "Empires need creeds to sustain their expansionist energies and provide them with a justification for domination" (Gascoigne 2008:159). In addition, religion also satisfies deeper needs of insecurity amongst empire builders. "Beneath the rhetoric and bravado of empire there is a profound if repressed undercurrent of doubt - as there is when human beings set themselves up as bearers of extraordinary power, authority and permanence" (Hall 2007 35).

14 The chief human consequence of this revolution is on the level of human identity which "is becoming the main, and sometimes the only, source of meaning in an historical period characterized by widespread restructuring of organizations, delegitimation of institutions, fading away of major social movements and ephemeral cultural expressions" (Castells 2000:3).

15 These identities involve 'the reconstruction of defensive identities around communal principles' (Castells 2000: 11).

16 "Cults represent one aspect of a worldwide epidemic of ideological totalism, or fundamentalism. They tend to be associated with a charismatic leader, thought reform, and exploitation of members." (Lifton 1981: 8) 
Anti-empire within this paradigm happens when "people subjected to foreign imperial rule mount serious resistance by renewing their own traditional way of life" (Horsley 2003:5). One example of this is the response of ancient Judea to Hellenistic and Roman power (:74-92). Another is Modern Iran's Islamic revival (:47-73). This renewal is not just a return to a traditional way of life but often a revision which strengthens those factors which have the power to resist empire to the detriment of others aspects of the tradition. It may also incorporate new sociocultural trends such as urbanisation. In addition there is usually the incorporation of elements of empire that are helpful. The use of information technology by Al Qaeda, and the use of modern Western education in African resistance to colonialism are two examples of this.

\section{When Religion Dominates Empire}

In this case we are often referring to empires of religious fundamentalism. In such a case it is religion that determines the fundamentals and the foundations of the empire. The early experience of Israel as it marched out of Egypt and wandered for forty year imposing itself on surrounding lands and entering the Promised Land provides the paradigm for this case. Here Yahweh is a tribal war god, David is a warrior king, and messianic expectation is the centre of belief (Cobb 2003 §1). But it should also be noted that this case also includes empires where the political authority asserts a role within religious leadership.

Empires where religion dominates have existed throughout time. Examples include the Holy Roman empire "when Charles the Great created a notion of Christian universality" (Herrin 1987:8) and some Islamic empires such as the Safavid in Iran "who established Shi'ism as a state religion and suppressed all other religious practices" (Carey H. 2008: 185).

Anti-empire responses to such empires emphasise resistance on the on the level of religion. These included theological resistance indicating perceived errors in its teaching and ethical resistance to the practices of the religion especially the abuse of power in its leadership. Examples include all the forms of Christianity which emerged between the 10th and the 16th century in response to the Catholic or Orthodox Churches. Some of these are dressed below.

\section{A Dialectic of Control}

Today's context of the globalised networked world is a good example of power relations between religion and empire in flux with neither having hegemony. Christianity, Islam, Hinduism and Buddhism have both empire supportive groups and anti-empire groups within them. I would argue that an analysis of the state of flux between religion and 
empire is likely to provide a better understanding of society even when one of them has hegemony.

In the case of Christianity it has been noted that: "Christianity and Empires, then, have often been yoked together but the marriage has rarely been secure nor has its offspring been clearly the progeny of both parties" (Gascoigne 2008: 174). On the one hand Christianity promoted empire as "Missionaries provided a network which could provide basic stores and services for a whole range of empire builders" (:168). In addition, missionaries have been accused of being agents of cultural imperialism and culture change amongst dominated peoples (:170-171). Yet Christianity grew. On the other hand the collapse of the empire can promote religious growth. "In much of the globe Christianity has actually grown spectacularly with the collapse of empires...in Africa during the period of decolonisation from 1965 to 2000 the number of those describing themselves as Christian has grown from approximately 75 million to 351 million" (:174).

\section{Empire and its Theology}

\section{Theologies of Empire}

Theologies of empire are theologies of power. They are concerned about the way in which power is conceived within religion and how this has an effect in the world. Empire constructs theology in two ways. First, it looks for theological symbols within religion that can be appropriated for the justification of its political and economic agendas. Secondly, it looks for cultural symbols of power within empire that can be reconstructed theologically to bolster the ideology and practice of empire which is expansionist, conquering and dominating.

Yahweh, like other tribal deities was understood as a tribal God....We identified the warrior God as our God and when we came into political power we frequently claimed God's support for military conquests....The Christian goal was to convert all people. This universalistic thrust, by the time of Charlemagne, justified the use of armies to extend the power of the Church (Cobb $2003 \S \S 1$ and II).

The theological category "God's chosen people" was adopted by Christian colonisers in their relationship with those they invaded who were considered to be in need of civilisation and Christianity. In the 19th century the Dutch, British and French considered themselves Christian civilisations with a duty to civilize the conquered. Often it was applied ethnically: "Northern Europeans, in particular considered themselves as shouldering the white man's burden" (Cobb 2003 §II)

The second way empire constructs theology by theologising culture or what is now called inculturation. One way this is done is through images of Jesus "shaped by empire at significant turning points" (Rieger 2007: vii). A 
striking illustration of this is the claim that the many titles applied to the Roman emperor were assumed onto Christ. "Before Jesus the Christ ever existed and even if he had never existed these were the titles of Caesar the Augustus: Divine; Son of God, God, and God from God; Lord redeemer and savior of the world" (Crossan 2008:73).

Anselm's theology of the atonement is clearly rooted in the notion of honour in medieval culture and the practice of honour sacrifice. Only someone of sufficient rank could make the appropriate honour sacrifice. "Anselm's claim that only a God-human can restore the violated honor of God and thus effect salvation is developed in the context of medieval empire formation" (Rieger 2007: 14).

\section{Theologies of Anti-empire}

Theologies of anti-empire are theologies of resistance to domination. There are two basic processes in their construction. The first looks for theological symbols and categories within their own religious narrative which are critical and condemnatory of the oppressive, exploitative and corrupt nature of empire. The second examines cultural values and practices within their local context which are supportive of their existence outside of empire. It then looks for ways to construct a theological narrative out of these within the emerging religious belief system. Theologies of anti-empire are thus attempts to construct theologies of resistance to the comprehensive power of empire.

Examples of the first approach abound in the scriptures: "once we start looking for them, issues of imperial rule and response to it run deep and wide through most books of the bible....Biblical texts have been used to justify imperial rule and to motivate resistance to oppressive imperial domination" (Horsley 2008: 7). In the Old Testament, we have seen how the Prophetic books are strongly condemnatory of empires which confronted Israel. In Isaiah 10, "verses: 8-11verbalize the arrogance of the empire, as Assyria imagines that Jerusalem is like other conquered capital cities, and YHWH the idol in Jerusalem, is like other defeated idols" (Brueggemann 2008:31). In addition, many of the prophetic texts include a call to Israel and Judah to abandon corrupt practices and foreign gods and to return to the practice of their covenant with Yahweh.

Black Theology used the Exodus story to interpret the context of Apartheid oppression: "In Black Theology salvation is first seen as liberation from oppression. It is the liberation which Yahweh wins for his people: the Exodus event which lies at the centre, and is the sustenance, of the life of Israel" (Boesak 1977:18).

The book of revelation has been called "the most explicitly counter imperial book in the New Testament" (Carey G. 2008: 157). It presents a symbolic prophetic vision of the Roman Empire whose "exercise of imperial domination as the sole superpower accompanied 
by economic exploitation for the benefit of the metropolitan elite, is under God's judgement" (Horsley 2008: 181).

One example of the second approach is found in the Maccabean revolt against Hellenes (Dan 12:1-4; 1 Macc 1-2). It presents the proponents in the discourse of triumphant Hellenization of Israel against the Jewish nation faithful to the law. The text is a religious history of the perseverance of ancestral history against gentile infiltration and hegemony in Israel.

Paul's transition from persecutor to apostle "must be understood in light of the political experience of Judeans under Roman rule" (Elliot 2008:103). There had been a number of Judean uprisings in cities of the Roman Empire which had been ruthlessly crushed by the authorities. Saul knew that the message about a man crucified by Rome proclaimed as "God's chosen king who would soon return to rule the peoples.... would inevitably have sounded subversive in Roman ears ... and bring repercussions against vulnerable Judean communities throughout the empire" (:103-104). This motivated his campaign against these people. Upon his conversion to Christ he clearly knew what the consequences of becoming an apostle would mean on the socio-political level. His texts, which often rework the Jewish tradition within the Christian context, have to be read within that framework of a radical commitment to the Gospel and its consequences.

Theological narratives of anti-empire were constructed from within local sociocultural traditions within Bogomilism, the Bosnian Church, the Cathars, the Reformers and other anti-empire groups. The resistance elements in African Indigenous Churches have been well documented. They represent a resistance to white leadership and to colonial forms of worship and do this by incorporating traditional African values and Cultural Practice into their Christianity (Villa-Vicencio 1988:35).

Theologies of anti-empire are thus attempts to construct theologies of resistance to the comprehensive power of empire.

\section{Theology of Authority}

Theologies of empire are theologies which try to persuade the masses of the transcendent value of empire. They are thus theologies of persuasion. In some ways (though clearly not all) they can be compared to the first part of the gospel message which attracted the crowds (Mark1-8). Theologies of anti-empire and resistance are theologies which confront evil in the world created by empires. In some ways they are like the later gospel message of the journey to Jerusalem and the passion (Mark 8-15). So these two kinds of theologies are good in themselves but are incomplete in their essence. Both are a prelude to the paschal mystery which is the essence and centre of the gospel. The death and resurrection of Jesus is a 
transformation to new life. In the end transformation occurs through the power of God in accordance with his will.

After his resurrection Jesus says "All authority in heaven and on earth has been given to me, go and make disciples" (Matthew 28:18). Authority (exousia; $\dot{\varepsilon} \xi o v \sigma i ́ \alpha)$ is a key Christological category It "denotes his divinely given authority to act" (Foerster 1964: 568). Such authority "Comprises both right and power" (:568). The historical Jesus "claims the same exousia (cf. Mt 11:27 with Mt 28:18) but within the limits of his earthly calling and commission" (:568).

In the Matt 28 pericope the text is linked spoken by the resurrected transformed Christ. The paschal mystery is of itself a transformational event manifesting the transformation of creation itself (Cf. Rom 8). Post resurrection authority is specifically linked to human transformation in the resurrected Christ. This is the key meaning of the Mathew 28 pericope where authority (exousia) has a different nuance to its pre-resurrection usage. "Jesus is exalted to be Christos and kyrios in the basileia tou theo" (Foerster 1964:568).

With the commissioning of the apostles Jesus imparts this authority to them in this text. "In the varied use of $\dot{\varepsilon} \xi o v \sigma i ́ \alpha$ for the authority imparted to the community, the outstanding characteristic is that the Church owes its existence and nature to Christ" (Foerster 1964:568). And his disciples are commissioned to be the apostles of this message of transformation of the world thorough the power of the risen Christ. This is the essential meaning of transformational authority in the missionary period which begins at Pentecost

Neither empires nor resisting groups of anti-empire exercise power in this way. Empires dominate and anti-empire resists to preserve itself. Consequently the goal of Christianity in society is always to mission for its transformation. The Christian vision of salvation through suffering, death and resurrection of the weak is eminently appropriate to this task. Theology of authority and its articulation in Christian praxis and mission is the essential response to empire and anti-empire. What does this mean in Africa today? An example from apartheid South Africa is helpful

Authority carries two components of power with it: the ability to exercise power and the consent of those over whom it is exercised. During the apartheid era the Catholic Bishops used this concept to indicate the difference between oppressive regimes and ethical societies.

Authority lies within the realm of power. If the powerful will works through the freely consenting will of others in a common domain of reality, power assumes the force of authority. So long as authority serves the common good it is properly or ethically exercised. 
But if it is unfairly exercised for one person's or a group's advantage, then it is abused (TAC 1985: 15).

\section{The Specific Context of Africa}

\section{The Church in Africa: Empire and Anti-empire}

The Church in Africa has seen empire and anti-empire from its early arrival in the north to more recent empires in sub-Saharan areas. Donatism was the most important anti-empire response in early African Christianity. It was named after the Berber bishop Donatus Magnum and established as a reaction to the persecution of Christians in North Africa by the emperor Diocletian (Chapman 1909). There were social, cultural and political characteristics to the Donatist group who were mainly "Numidian peasants and Carthaginian lower classes" (Nthamburi 1981:216). The Catholics were more closely linked to the Roman world. Donatism has been described as "an indigenous form of Christianity vis-à-vis Catholicism" (:218). It clearly manifests the two typical dimensions of anti-empire discourse: socio-cultural differences and religious dispute. "There was a clash of civilization expressed in terms of religious dogma" (:218).

Christian colonial empire came to sub-Saharan Africa in the 15th century when the Portuguese arrived in Congo, followed by the Dutch in the Cape in the 17th century. Colonial ingression was more extensive during the nineteenth century when British, French, German and Belgian colonialism spread everywhere in the sub-Saharan region.

In South Africa, "The moment that the Afrikaners gained political control they implemented their own empire" (Oliver 2010). The theological justification for its existence was based on Afrikaner Calvinism, the ethnic structure of its church under white control and the influence of Kuyper on the theology of Apartheid. ${ }^{17}$

Anti-empire resistance took a number of forms. One was in African Nationalist movements often led by leaders trained in mission schools. Another was in the emergence of African indigenous churches initially as a reaction to the lack of leadership possibility in traditional churches. The theological category of Zion and its links to land has been particularly important in the south. Regarding Bishop Mutendi of the Zion Christian church in Rhodesia (Zimbabwe) it has been said:

In a sense, his Zion City to the Chiefs became a 'half-way house' between the traditional religious authorities and the radical African nationalistic factions, a protective refuge where the chiefs could participate in the subtle resistance of their people to the infiltration of foreign influence without entirely jeopardising their positions in relation to the European Administration on whom they depended (Daneel 1983:62).

17 For a detailed consideration of this matter see Manavhela 2009. 
Some resolution was achieved in the independence of previously colonised African states but this occurred during the period of the cold war which led to a new form of colonisation based on patronage to either first world or second world nations. Both the USA on the one hand and Russia and China on the other expanded their influence and control by financing and supporting a series of client dictators or undemocratic regimes bought into power or entrenched in power by money and arms. Examples include Apartheid South Africa, Mobutu's Zaire, Dos Santos' Angola and many others.

In Africa today, however, the situation is somewhat different as we are witnessing the rise of a new empire and South Africa is trying to be a player in it.

Elsewhere I have pointed to the significance of South Africa joining the BRIC group of developing countries after intense lobbying by President Zuma. ${ }^{18}$ This bloc represents $40 \%$ of the world's population. It has shown massive growth since 2000 and is estimated to become the world major economic power group by 2032 when the GDP of the BRIC countries will be larger than the first world bloc called G7 (Goldman Sachs 2007: 138) ${ }^{19}$ South Africa has been asked to join the BRIC countries because of its international profile and also because it is the portal into Africa whose countries are now the world's fastest growing. There were six African countries in the world's top ten fastest growing economies between 2001-2010: Angola, Nigeria, Ethiopia, Chad, Mozambique and Rwanda (Economist 2011). ${ }^{20}$

The BRIC countries currently have an anti-empire profile seeing themselves as a model for poor countries and they lobby for fairer international trade relations with are currently biased in favour of first world countries. They recognise the importance of the UN Millennium Declaration and the need to achieve the Millennium Development Goals (MDGs). ${ }^{21}$ It is entirely possible that by the middle of this century they will begin to take on the nature of empire leading to a massive change in the nature of the world. What consequences do these changes have for African Christian Mission in the future?

18 Bate, S. 2012. "Faith and secularism in the context of developing countries: A pastoral response." Missionalia 40, 1 \& 2: 77-104.

19 The report also predicts that Nigeria will be the largest African economy with the same GDP as Germany and slightly larger than France (Goldman Sachs 2007:174). The G7 (Group of 7) nations are US, UK, Canada Germany, France, Italy and Japan

20 The article also comments: "On IMF forecasts Africa will grab seven of the top ten places over the next five years".

21 They cooperate in providing "technical cooperation and financial support to poor countries in implementation of development policies and social protection for their populations" (BRIC 2010) 2nd BRIC Summit of Heads of State and Government - Joint Statement - Brasília, April 15, 2010. 


\section{African Christian Mission in a World of BRICS, Globalisation and 21st Century Information Technology}

If Africa finds itself between anti-empire during the colonial period and possible pre-empire in the globalised networked world then an evaluation of missionary vision and priorities is necessary within this rapidly changing context. In my view this requires a missiology centred on transformation through authority, founded on the paschal mystery. This will allow it to move beyond the empire/anti-empire paradigm. Such a missiology needs to respond to the socio-cultural, economic and religious trends that are emerging in the globalised networked world as well as the specific trends reflecting needs of emerging African economies. The missiological method requires two moments. In the first place it should examine significant sociocultural, economic and religious trends in this context. These should then serve as the context for proposals about priorities for mission and ministry.

\section{Sociocultural, Economic and Religious Trends in the Globalised Networked World}

A number of trends are likely to affect the African continent during this globalised networked century. Some are common to the culture of the globalised networked world, reflecting symbols and root metaphors within it. In addition there are a number of trends which specifically affect the emerging developing economies of Africa. All can be analysed in terms of the following social categories.

\section{Socio-Philosophical}

On the socio-philosophical level we are likely to see a continuation of the move of religion to the realm of the private. Consequently, religion will be increasingly dismissed by those post-modern secular states governed by a grounding constitution of which South Africa is a prime example. This dismissal of religion by society will be particularly evident in the growing irrelevance of religions as participants in the social debate about right and wrong in society. This of course is the secularism paradigm. A second trend linked with this, but in fact anterior to it, is the dismissal of transcendence as a source of morality and absolute truths in favour of postmodern glocalised pragmatic solutions. ${ }^{22}$ This is the metaphysics paradigm.

22 "The neologism "glocalization" has emerged in recent years in economic, sociological, and cultural theories in response to the proliferation of writings about globalization and its local implications. It might best be described as the relationship between global and local processes, which are increasingly viewed as two sides to the same coin rather than being diametrically opposed. The age of global mobility has created more fluid and seamless relationships. For example, the work of Castells (20000) on the network society...give some indication of how global mobility has affected local environments and their inhabitants" ("Glocalisation" Blackwell) 


\section{Socio-ethical}

On the socio-ethical level we are likely to see an increasing prioritising of materialist concerns to the detriment of ethical behaviour and concern for the exploited. This is the justice paradigm. As a result of this, the marginalised in society will begin to develop resistance identities, or anti-empire identities advocating either engagement with violence or withdrawal into dependency driven glee states like substance abuse or religious searches for transcendent experiences of euphoria outside daily life. This is the resistance-coping paradigm.

\section{Socio-economic}

On the socio-economic level there will be a growing gap, globally, between the rich and the middle class on the one hand and the poor on the other. The characteristic of the rich and powerful is their ability to access and control information technology for capital, financial, political and media control goals. The principal characteristic of the poor will be its increasing intranational nature rather than international one. ${ }^{23}$ This is the solidarity paradigm. Unemployment will be the primary sign of the poor. Lack of access to human development will be one of its principal causes. This is the development paradigm.

\section{Socio-Religious}

Religion will take on a number of characteristics. One is in small groups of fundamentalist believers creating resistance identities and using violence (Castells 2000: 12). This is the anti-empire stance. Another will be a continued growth of consumer religion groups such as the coping-healing churches which offer a consumer approach to religion based on personal needs. Here the priority is immediate experience rather than permanent commitment. This is the co-option by empire stance. A third will be a growing anomie concerning traditional forms of religion which no longer meet the religious needs of people today. Linked to this will be an on-going search for meaning in life with the collapse of the category of transcendence to be replaced by human self-fulfilment. All these characteristics can be placed together within the spirituality paradigm because they all result from the search for authentic spirituality in life today.

It is my contention that the secularism paradigm, the metaphysics paradigm, the justice paradigm, the resistance-coping paradigm, the solidarity paradigm, the development paradigm, and the spirituality paradigm must be addressed within an authentic missiology for the future in

23 Globalisation will see a move away from the rich countries/poor countries paradigm of the modern colonial period to a rich and poor within countries paradigm. This is because globalisation will bring a similarity of social and economic scenarios to all areas of the world. 
developing countries in Africa. The paradigm within which such a missiology should be constructed is that of transformational authority in the sense we have argued for.

\section{Mission and Ministry in a Globalised Networked Africa}

The response of mission and ministry to these trends requires both a missionary vision and ministerial strategies. A start can be made by promoting the following eight goals which address the issues identified in our analysis:

\section{Mission to Socio-philosophical concerns}

\section{Promote transcendence against secularism (a transformation response to the secularism paradigm).}

Max Stackhouse has pointed out that social science today understands the nature of power in society to be "the socially constructed patterns of economics, culture, and, especially of politics...This threefold analysis of the powers is widely used in contemporary scholarship" (Stackhouse 2009: 5) .

This secular analysis relegates theology to the domain of religion and religion to the domain of culture in modern scholarship. Religion and ethics are seen as "a mostly benign expression of cultural development...that has no formative, regulative, interpretive or guiding role in globalisation or in understanding the forces producing it" (Stackhouse 2009: 9). This argument is weak for at least two reasons. First, the power of religion is growing in the world rather than diminishing. Second, "these three levels of social power do not take account of what transcends them" (Stackhouse 2009:5).

It is difficult to deny that "the moral and spiritual architecture of every civilisation is grounded, more than any other factor, in religious commitments that point to a source of normative meaning beyond the political, economic and cultural structures themselves" (Stackhouse 2009:11). This is an argument of transformational authority.

I would place transcendental norms largely within the realm of religion for this is by far the most common situation. I am aware that the term is also used by others outside the realm of religion. Graves (2009: 529 note 3), for example, says:

I differentiate between the transcendent, which refers to ontological and metaphysical unknowables of which many religions consider some aspects divine; the transcendent level, which refers to a level of human systems emerging from cross-cultural interactions; and the transcendentals of Good, Beauty, and Truth.

He denies that transcendent-level phenomena can only be approached through culture since if this is true "how can one gain a nonrelativistic, natural appreciation of those norms?" (Graves 2009: 508). He thus opts for "an emergent, transcendent level that includes the transcendental norms historically characterized as the Greek Good, Beauty, and Truth. These 
norms require a dynamic existence similar to Spirit in Royce's community of interpretation. (:528) ${ }^{24}$

Without the promotion of foundational ethical values coming from transcendental norms which are generally rooted in religion, societies have "no ethical principles behind them, no interest-guiding spirit in them and nothing more governing them than the struggle to get and keep political power, economic wealth and cultural sovereignty" (:7). Events in many countries today would suggest that this is happening already. The situation is particularly acute in developing societies which undergo rapid social transformation leading to cultural, moral and environmental turmoil. We are seeing many signs of this in South Africa today.

\section{Articulate the role of religion in society today (a transformation response to the metaphysics paradigm).}

The role of religion in modern societies was the topic of a dialogue between Jurgen Habermas and Joseph Ratzinger in January 2004. Habermas had previously conceded that values such as human dignity, morality of consciousness and democracy are the legacy of "the Judaic ethic of justice and the Christian ethic of love...up to this day there is no alternative to it" (Habermas 2002:151). In his paper he affirms that secularism has been superseded by a post secular society in which religion continues to flourish and states: "I do not wish to speak of the phenomenon of the continued existence of religion in a largely secularised environment simply as a societal fact: philosophy must take this phenomenon seriously from within, so to speak, as a cognitive challenge" (Habermas 2006:38; my italics). Consequently, he concludes: 'In the Post secular society, there is an increasing consensus that certain phases of the "modernisation of the public consciousness" involve the assimilation and reflexive transformation of both religious and secular mentalities' (:47).

In his paper, Ratzinger (now Pope Benedict XVI) asks: How can the question of the ethical foundation of law be resolved? He argues that it cannot be resolved through majority will as there are many examples where the majority has imposed injustice on the minority. Nor indeed can it be resolved on norms coming from the modern period alone since "Islam has defined its own catalogue of human rights, which differ from the Western catalogue" (Ratzinger 2006:61) and China "is asking whether "human rights' are merely a typically Western invention - and one that must be looked at critically" (:61). In addition both religion and reason have to be doubted since, individually, each has sometimes led to violence (63-66).

$24 \mathrm{He}$ goes on to argue that transcendentals exist within the transcendent level (Graves 2009: 529 note 3) 
Ratzinger concludes that only an analysis of power and law in terms of both religion and reason can promote a discussion leading to an ethic to inform law. "Accordingly I would speak of a necessary relatedness between reason and faith and between reason and religion, which are called to purify and help one another" (Ratzinger 2006:78). In addition he suggests that such a discussion needs to take place within the intercultural context of the world today "It is important to include the other cultures in the attempt at a polyphonic relatedness, in which they themselves are receptive to the essential complementarity of reason and faith" (:79).

Ratzinger's views create a major task for theologians in the globalised networked world today. The promotion of the centrality of religion in the analysis of power and law in society is one of the central tasks of theology today and shows the need for academic institutions of theological research. This is an argument of transformative authority.

South Africa as a constitutional democracy follows the three fold analysis of power in society presented by Stackhouse. It is noticeable that Universities in South Africa are removing faculties or schools of theology and placing them under schools of religion or culture. It may be increasingly important for faith based organisations to establish tertiary academic institutions approved by the Department of education and accredited by the Council for Higher education. ${ }^{25}$ Networking amongst these institutions focussing on the contribution of theology to global society will be essential in future. It will also help promote matters found in the recent signed South African Charter of religious rights and freedoms as required by section 234 of the Constitution. ${ }^{26}$

\section{Mission to Socio-ethical Concerns}

\section{Promote transformation identities against resistance anti-empire identities (a transformation response to the resistance-coping paradigm).}

When anti-empire limits itself to resistance against empire it creates identities predicated either on engagement through violence or withdrawal into dependency driven glee states such as substance abuse or para-religious, forms of euphoria. These two identities are manifestations of the resistance-coping paradigm.

Faced with the power of empire, Christianity must promote transformation as the final goal for human identity and commitment. If Castells is right, and the quest for human identity is to be one of the

25 The Catholic Church has done that with the establishment of St Joseph's Theological Institute and St Augustine College as tertiary academic institutions in South Africa. The latter was established as a Catholic University in 2009. Many Protestant schools are also following this path.

26 Signed at the University of Johannesburg on 21 October 2010. See Benson 2011. 
prevailing issues of the information revolution, then new Christian identities are needed as a legitimate response to human identity needs in a networked society. The Church has a major mission here. The challenge will be to offer a coherent, comprehensive identity for humanity in the globalised information age. Such an identity should not just be a resistance identity but must provide a vision for transforming the network and the global world. The Christian vision of salvation through suffering, death and resurrection of the weak is eminently appropriate to this task and is a statement of transformational authority. The task of missiology is to continue to develop theological responses that address issues and problems that result from global systems. ${ }^{27}$ Theologies of development, liberation, inculturation, feminism, ecology and human rights are examples of theological responses which have been helpful in establishing Christian identity amongst networked groups. ${ }^{28}$

\section{Promote morality against selfishness (a transformation response to the justice and solidarity paradigms).}

The prioritising of materialist concerns to the detriment of ethical behaviour and concern for the exploited is a major manifestation of global empire. Christian mission must continue to promote the construction of a Christian ethic of justice in a world where bankers receive obscene bonuses whilst ordinary citizens are being made to pay for the financial crisis since 2008. Much of the protest in Europe and North America is about this injustice which increases the gap between rich and poor everywhere.

Pope John Paul II constructed such an ethic on the theological anthropology of human solidarity. In 1987 he wrote: "in a world divided and beset by every type of conflict, the conviction is growing of a radical interdependence and consequently of the need for a solidarity which will take up interdependence and transfer it to the moral plane" (SRS §26). Such solidarity "is valid when its members recognize one another as persons (SRS §39). It places demands on all those:

who are more influential, because they have a greater share of goods and common services, should feel responsible for the weaker and be ready to share with them all they possess. Those who are weaker, for their part, in the same spirit of solidarity, should not adopt a purely passive attitude or one that is destructive of the social fabric, but, while claiming their legitimate rights,

27 In applying the global concept of 'flow' to theology Schreiter (1997:x) posits the notion of 'global theological flows' that are a kind of coherent comprehensive theological narrative/discourse which addresses a particular human condition. They have a global dimension to them because they deal with issues which occur throughout the global system.

28 Schreiter (1997:16) suggests that religion can be helpful to the networked society by providing answers to 'alienating and impersonal' global systems. Religion can do this by providing 'the telos that global systems lack'. 
should do what they can for the good of all. The intermediate groups, in their turn, should not selfishly insist on their particular interests, but respect the interests of others (SRS §39).

The transformation of South Africa since 1994 has brought political freedom, economic growth and development as well as sociocultural self-determination. This is an act of transformational authority. However there have been consequences in that previously hidden social contexts of marginalisation and suffering in our country have become more visible. In addition there are many examples of the moral breakdown of social structures within which people can feel safe and protected and live fully human lives. Today we especially need a church which promotes a moral vision on the level of social and societal interaction. Indeed "the root mission of the churches is to work to inform the moral sensibilities of market societies so that the respect and enhancement of the integrity of life are basic to the self-understanding and ethos of a society" (Schweiker 2000:138).

\section{Mission to Socio-economic concerns}

\section{Promote local mission to the unemployed (a transformation response to the justice paradigm).}

Given that unemployment as an intrastate phenomenon, will become a major signifier of poverty in the globalised networked world, an important aspect of the promotion of justice will be in the mission to the unemployed. Obviously there are many ways in which this mission can be articulated. I would like to make a few suggestions here.

Firstly the Church can provide resources to help the poor who are characterised by disconnectedness from the network and its resources. Great creativity will be required to develop cost effective uses of electronic networks for mission to the unemployed. This is a major challenge for mission today. Such access could provide a free source of information, and skills training for the unemployed. It can also help in providing ways to set up small scale local businesses. Information technology through social media can also be used to provide more effective advocacy for the unemployed.

Secondly the Church will need to continue and improve its response to human needs on the physical and structural levels. On the physical level we will continue to need those who will offer food, shelter, and hope to the destitute, homeless and unemployed. The need for organisations such as Mother Theresa's Missionaries of Charity is not likely to end soon. On the structural level, it will be important to help people improve their social infrastructure in order to improve the quality of life of the marginalized.

Globalisation means that Church organisations will increasingly have to cooperate with other like-minded organisations for social upliftment of the poor. A striking example of this was the cooperation between Catholics 
and communists in Kerala, India in literacy campaigns, health care and housing (Morar 2002: 99-105; 156-159).

Mission to the poor will continue to have a political dimension in advocacy for better and more just conditions for the poor respecting of the dignity of all. Advocacy will also need to operate on the global level in the struggle for an international order that can respond to the deleterious effects of the emerging global empire including unbridled capitalism and the rise of globalised crime.

\section{Promote human development (a transformation response to the development paradigm).}

Mission will need to focus on human development, something that is not new. During the colonial era the focus was on mission schools, mission hospitals and clinics as well as development programmes in agriculture. Today, a focus on human development will to focus on Africa as a site of emerging market countries such as the BRICS. There is a real opportunity for collaboration between African governments and churches in the setting up of development programmes for the poor in order to help them participate in the growth that will come. The prophetic words of Pope Paul VI in his encyclical Populorum Progressio ring particularly true today. Elsewhere I have indicated how they prefigure the Millennium Development Goals. ${ }^{29}$ Areas of missionary activity include skills training programmes, specific development programmes in the major centres of unemployment (rural areas and informal settlements) and adult education programmes including literacy, health care, and housing.

The promotion of human development amongst the poor as a sign of solidarity is further enhanced when such development is financed from within the society by the rich. Paul VI wrote: "There is no progress toward the complete development of women and men without the simultaneous development of all humanity in the spirit of solidarity" (PP §43). Evangelisation of the rich regarding human solidarity is thus a prime activity of the mission for human development.

\section{Mission and Evangelisation.}

\section{A Church which promotes conversion (a transformation response to the spirituality paradigm).}

Faced with a new context and new human needs, the first response of Christians must be openness to conversion. This is a renewed conversion to Jesus Christ and his presence in the people of this world today. Conversion happens when we find a treasure hidden in a field (Mt 13:44). Such conversion sees the presence of God in the new context of our world. It

29 "Faith and Secularism in the Context of Developing Countries: A Pastoral Response". Missionalia Forthcoming 
moves us away from former, familiar and even self-centred practices towards providing hope and transformation in the future. This good news is God's message to us because conversion always comes from God.

Conversion leads to a commitment to the poor who are blessed; and away from a religion of wealth and blessing for me and mine. It also requires a search for new spiritualities to respond to this time. The emergence, within the networked society of groups and organisations such as feminists, ethnic and cultural minorities within nations, gays and lesbians and others like these, together with the resurgence of older cultural traditions worldwide, requires a cultural understanding of such groups in order to develop missiological approaches which speak within their social space (Cf. Bellagamba 1992:2). The Church in Africa will need to respond to the challenge of cultural change brought about by the inpact of globalisation, information technology and development challenges.

All of these matters are issues within the discourse of inculturation leading to the well-known criteria for authenticity: "compatibility with the Gospel and union with the universal Church" (EA §62). Mission implies spreading the gospel in ways that are culturally intelligible and become good news to people within their own context. ${ }^{30}$ Indeed, 'good news' in the sense we have described it should be the principal litmus test for any missionary work we do. Is it good and is it new in this social context?

\section{Promote authentic religious experience (a transformation response to the spirituality paradigm).}

In a globalised networked world, immediate experience will be prioritised over learned behaviour. For Christianity this implies the increasing importance of personal religious experience. Bellagamba (1992:3) calls the revival of religious experience a 'megatrend' as people 'are thirsting for the divine' throughout the world. However, a lot of what passes for religious experience contains aspects of psychosocial manipulation. Consequently we need a missiology of religious experience that includes insights from psychology and anthropology as well as the theology of spiritual discernment. ${ }^{31}$ Greater understanding of the phenomenon will help to develop authentic approaches to evangelisation which help people to

30 Hoedemaker (in Kirk \& Vanhoozer 1997: 218) points out that missiology has always 'had more affinity to cultural studies than to philosophy'.

31 For many people, their first religious experience is one of being healed by a faith healer. These moments can often be evangelising for the person who then joins the new faith. Such religious healing rituals always include some kind of emotional experience which, in its simplest form, moves from negative feelings of fear, anxiety and concern to positive feelings of wellness, security and hope. Sometimes mechanisms such as catharsis can make the healing experience a very powerful one for the subject.. See Bate (1999:61-122)) for a psychological and anthropological analysis of religious healing techniques particularly in Pentecostal and African Independent Churches. 
experience the presence of God in their lives and reorientate their lives to him without emotional manipulation by practitioners. ${ }^{32}$

Popular Catholicism remains a vital means of access to religious experiences "which satisfy their needs in life and work... They show that religion is for the people and not vice versa" (Amaladoss in Bamat \& Wiest 1999: 272). We will see an increasing growth in the importance of Shrines, Pilgrimage centres, retreat centres and Mass religious revival events as some of the strategies for Church mission.

These matters raise the question of liturgy and worship. Indeed, it has been said that the response of Christianity to a globalised world requires "a liturgical vision through which Christians may learn to look at God's world through God's eyes" (Conradie 2011:7). This vision recalls the Church to a re-grounding of its Mission in the Mission of God recognising the liturgy provides us with our deepest insight into God's will. "The heart of the liturgical vision is Christian worship. Here the body of Christ rediscovers something the identity and character of the triune God...Put differently, the liturgy is the place where we learn anew to recognise God" (:7).

\section{Conclusion}

Religion, empire and anti-empire are found in most societies. Currently Africa finds itself between empire and anti-empire as it moves into the 21st century. Social and religious trends here can be defined in terms of the secularism paradigm, the metaphysics paradigm, the justice paradigm, the resistance-coping paradigm, the solidarity paradigm, the development paradigm, and the spirituality paradigm. The empire/anti-empire dialectic can be resolved in terms of a missiology based on transformational authority centred in the paschal mystery. Such a missiology should promote transcendence against secularism, articulate the role of religion in society today, promote transformation identities against resistance identities, promote morality against selfishness, promote local mission to the unemployed, promote human development amongst the poor and promote authentic conversion and authentic religious experience.

\section{Bibliography}

Balkin, J. 1998. Cultural Software: A Theory of Ideology. New Haven: Yale University Press.

Bamat, T. and Wiest, J. 1999. Popular Catholicism in a World Church. Seven Case Studies in Inculturation. NY: Orbis.

Bate, S. 1999. The Church under Apartheid, in Brain, J, \& Denis, P. The Catholic Church in Contemporary Southern Africa, 151-186.

32 See Carrier 1988: 47ff on psycho sociology of religious belonging. 
Pietermaritzburg: Cluster Publications.

Bellagamba, A 1992. Mission and Ministry in the Global Church. NY: Orbis.

Benson, I. 2011. South African Charter of Religious Rights and Freedoms. International Journal for Religious Freedom 4,1:125-134.

Boesak, A. 1977. Farewell to Innocence: A Socio-Ethical Study on Black Theology and Power. N.Y.: Orbis.

Boesak, A. 2009. Globalisation : The Politics of Empire, Justice and the Life of Faith. Stellenbosch: SUN Press.

Boff, L. \& Boff, C. 1984. Salvation and Liberation: In Search of a balance between Faith and Politics. N.Y.: Orbis.

BRIC 2010. 2nd BRIC Summit of Heads of State and Government - Joint Statement - Brasília, April 15, 2010, viewed September 2011, $<$ http://eng.special.kremlin.ru/ref_notes/5 >

Brueggemann, W. 2008. Faith in the Empire, in Horsley, R. ed. In the Shadow of Empire. Louisville, Kentucky: Westminster John Knox, $25-40$.

Carey, G. 2008. The Book of Revelation as Counter-Imperial Script, in Horsley, R. In the Shadow of Empire. Louisville Kentucky: Westminster John Knox, 157-176.

Carey, H. 2008. Religion and the "Evil Empire". Journal of Religious History 32,2: 179-192.

Carrier, H. 1988. Psico-sociologia dell'appartenenza religiosa. Torino: Elle Di Ci.

Castells, M 2000. The Information Age: Economy, Society and Culture. Volume I: The Rise of the Network Society. Oxford: Blackwell, 2nd edition.

“Cathari”. New World Encyclopaedia, viewed December 2011, $<$ http://www.newworldencyclopedia.org/entry/Cathari $>$.

Chapman, J. 1909. "Donatists". The Catholic Encyclopedia. Vol. 5. New York: Robert Appleton Company, viewed December 2011,

$<$ http://www.newadvent.org/cathen/05121a.htm $>$.

Cobb J. 2003. Christianity and Empire. Presentation at a Conference on American Empire at Drew Theological Seminary, September 25th 2003. Viewed November 2011, 
$<$ http://www.religion-online.org/showarticle.asp?title $=3350>$.

Conradie, E. 2011. Mission in a Globalised World: A New Vision of Christian Discipleship. A keynote address delivered at the conference of the Australian Association for Mission Studies (AAMS), Sydney, 22 to 25 September 2011. Viewed November 2011, $<$ http://groupsthatclick.com/files/aams/ConradieKeynote1.pdf $>$.

Crossan, J. 2008. Roman Imperial Theology, in Horsley, R. ed. In the Shadow of Empire. Louisville Kentucky: Westminster : John Knox: 59-74.

Daneel, M. 1983. Communication and Liberation in African Independent Churches. Missionalia 11: 57-93.

EA. Ecclesia in Africa. Apostolic Exhortation of Pope John Paul II, September 14 1995. Vatican.

Economist 2011. Africa's impressive growth. 6 January, viewed August 2011, < http://www.economist.com/blogs/dailychart/2011/01/ daily_chart >.

Elliot, N. 2008. The Apostle Paul and Empire, in Horsley, R. ed. In the Shadow of Empire. Louisville Kentucky: Westminster John Knox, 97-116.

Foerster, W.1964. exousia ( $\dot{\varepsilon} \xi o v \sigma i ́ \alpha)$, in Kittel, G ed Bromily G (trans.), in Theological Dictionary of the New Testament. Grand Rapids: Wm B. Eerdmans Publishing Company,562-574.

Friesen, S. 2001. Imperial Cults And The Apocalypse Of John: Reading Revelation In The Ruins. Oxford: University Press.

Gascoigne, J. 2008.Introduction: Religion and Empire, an Historiographical Perspective. Journal of Religious History 32,2: 159-178.

"Glocalisation". Blackwells Encyclopedia of Social Science, viewed December 2011, <http://www.sociologyencyclopedia.com/public/ tocnode? id=g9781405124331_yr2011_chunk_g978140512433113_ss1-62>

Goldman Sachs Global Economics Group. 2007. Brics And Beyond. NY: Goldman Sachs, viewed Nov 2011, $<$ www2.goldmansachs.com/our-thinking/brics/BRICs-and-Beyond .html $>$.

Graves, M. 2009 . The emergence of transcendental norms in human systems. Zygon 44, 3: 501-532

Gutiérrez, G. 1973. A Theology of Liberation. NY: Orbis. 
Habermas, J, 2002. Religion and Rationality: Essays on Reason, God, and Modernity. Cambridge Ma: MIT Press.

Habermas, J, 2006. Prepolitical foundations of the Democratic State, in Schuller, F. ed. The Dialectics of Secularisation. San Francisco: Ignatius: $19-52$.

Hall, D. 2007. Christianity and Empire, in Living Faithfully in the Midst of Empire, Report to the 39th General Council Toronto: United Church of Canada, Appendix A.

Halsall, P. 1997. "Theodosian Code XVI.i.2". Medieval Sourcebook: Banning of Other Religions. Fordham University. viewed Dec 2011, $<$ http://www.fordham.edu/halsall/source/theodcodeXVI.html $>$.

Herrin, J. 1987. The formation of Christendom. NJ: Princeton.

Horsley, R. 2003. Religion and Empire. Minneapolis, MN: Fortress Press.

Horsley, R. ed. 2008. In the Shadow of Empire. Louisville Kentucky: Westminster John Knox.

Kirk, J. and Vanhoozer, K. eds. 1999. To Stake a Claim: Mission and the Western Crisis of Knowledge. NY: Orbis.

Latourette, K. 1938. The Thousand Years of Uncertainty: AD 500-AD 1500. NY: Harper and Brothers.

Lifton, R. 1981. "Cult Formation." The Harvard Mental Health Letter Vol. $7,8$.

Manavhela, G. F. 2009. An Analysis of the Theological Justification of Apartheid in South Africa: A Reformed Theological Perspective. Vrije Universiteit, Amsterdam. viewed December 2011, < http://dspace.ubvu.vu.nl/bitstream/1871/13313/5/9017.pdf $>$.

McGrath, A. 1998. Historical Theology: An Introduction to the History of Christian Thought. Oxford: Blackwell Publishers.

McGrath, A..2006. Christian Theology: An Introduction. NY: Wiley-Blackwell.

Morar, M. 2002. Rethinking Liberation Theologies: The Cooperation between the Roman Catholic Church and the Communist Party (India) in Kerala: A Theological, Ethical Evaluation and Underpinnings for South Africa. Unpublished Master's thesis in Moral and Cultural studies. University of the North, Qwa qwa campus. South Africa.

Nolan, A. \& Broderick R.1987. Theology of Liberation for Southern Africa. 
Hilton: Cornerstone.

Nthamburi, Z. 1981. The Relevance of Donatism for the Church in Africa Today, African Ecclesial Review 23,4: 215-220.

Oliver, E., 2010, Afrikaner Christianity and the concept of empire. Verbum et Ecclesia 31(1), Art. \#393, 7 pages. DOI: 10.4102/ve.v31i1.393.

PP. Populorum Progressio 1967. Encyclical of Pope Paul VI on the Development of Peoples. Vatican.

Ratzinger, J. 2006. That Which Holds the World Together: The Prepolitical Moral Foundations of a Free State, in Schuller,F. ed The Dialectics of Secularisation. San Francisco: Ignatius: 53-80.

Rieger, J. 2007. Christ and Empire: From Paul to Postcolonial Times. NY: Fortress Press.

Schreiter, R. 1997. The New Catholicity. NY: Orbis.

Schweiker, W. 2000. Responsibility in the World of Mammon, in Stackhouse, M., Paris, P. eds. God and Globalization Vol. 1: Religion and the Powers of the Common Life. NY. : T \& T Clark International, 105-139.

SRS. Sollicitudo Rei Socialis. 1987. Encyclical Letter of Pope John Paul II. Vatican.

Stackhouse, M. 2009. Introduction, in Stackhouse, M. \& Obenchain, D. eds. God and Globalization Vol. 3: Christ and the Dominions of Civilization. NY: Continuum, 1-57.

TAC 1985. Theological Advisory Commission of the Southern African Catholic Bishops' Conference. The Things that Make for Peace. A report to the Catholic bishops and the Church in Southern Africa. Pretoria. SACBC.

Urquhart, F. 1908. "Christendom", in The Catholic Encyclopedia. New York: Robert Appleton Company, viewed November 2011, < http://www.newadvent.org/cathen/03699b.htm >

Villa-Vicencio, C.1988. Trapped in Apartheid. N.Y.: Orbis.

Weber, N. 1907. “Albigenses”, in The Catholic Encyclopedia. New York: Robert Appleton Company, viewed November 2011, < http://www.newadvent.org/cathen/01267e.htm>. 